\title{
Comparative study on the development of maize flour based composite bread
}

\author{
R. Begum*, M. J. Uddin, M. A. Rahman and M. S. Islam \\ Department of Food Technology and Nutritional Science, Mawlana Bhashani Science and Technology University, \\ Tangail-1902, Bangladesh, *E-mail: rokeya15@yahoo.com
}

\begin{abstract}
The study was conducted to develop composite bread with maize flour and also to evaluate the nutritional quality and sensory properties of resulting breads. The results of the proximate analysis showed that wheat and maize flour contain protein 12.56 and $9.08 \%$; fat 0.85 and $1.15 \%$; ash 0.62 and $1.60 \%$; fibre 0.68 and $1.25 \%$; gluten 12.11 and $0.0 \%$, respectively. Breads were produced from composite flour containing 10,20, 25, 30 and $40 \%$ of maize flour and compared with wheat bread for various quality attributes of the developed products. The incorporation of maize flour adversely affected the baking properties and dough expansion but the nutritional quality was improved in case of fiber and energy content. The sensory analysis showed that there was no significant difference between the wheat bread and bread with $10 \%$ maize flour. Substitution of $10 \%$ maize flour into wheat flour retained much of the nutritional and sensory properties and gave the bread with the good overall acceptability. It was found that volume and specific volume highly positively correlated with taste, texture and overall acceptability but negatively correlated with hardness. The sensory qualities such as hardness and springiness deteriorated during storage with increasing level of maize flour in the breads.
\end{abstract}

Keywords: Wheat flour, Maize flour, Composite bread, Physico-chemical Composition, Sensory attributes

\section{Introduction}

Bread may be described as a fermented confectionary product produced mainly from wheat flour, water, yeast and salt by a series of process involving mixing, kneading, proofing, shaping and baking (Dewettinck et al, 2008). Now it becomes a very popular ready food. The main ingredient of bread is wheat flour. The flour should have good amylase activity, the moisture content should be less than $14 \%$ and the color or appearance should be satisfactory (Giami et al, 2004). The whole wheat flour has been shown by many researchers to be a rich source of these functional ingredients such as fiber, photochemical, minerals, essential amino acids that are located in the bran and fat soluble vitamins contained in the germ of the whole wheat grain (Dewettinck et al, 2008). Due to the high cost, geographical scarcity and high demand of wheat flour, efforts are been directed toward the provision of locally available alternative source of flour such as maize, cassava, oats. Composite bread are a mixture of flours from tubers rich in starch (e.g. cassava, sweet potato) and protein rich flours ( e.g. soy, peanut) and cereals (e.g. maize, rice, millet, buck wheat) with or without wheat flour. Maize nutritionally is superior to others cereals in many ways, except in protein value (Mejia, 2003). Maize compared with wheat and rice is higher in fat, iron and fiber content. A weak nutritional aspect of maize is the quality of its protein since around a half of its protein is made up of zein, which is low in two essential amino acids, lysine and tryptophan. Fortunately this deficiency now a day has been corrected with the development of the quality protein maize (QPM), which is nutritionally the most superior cereal grain (Mejia, 2003). In developing countries the use of composite flour had the several advantages such as; saving the hard currency, promotion of high yielding, native plant species, a better supply of protein for human nutrition and better overall use of domestic agriculture production (Berghofer, 2000). Therefore the use of maize flour for production of baked goods would help lower the dependency of developing nations on imported wheat.

The objectives of this study were to develop maize flour based composite bread and compare with wheat flour bread in respect to physico-chemical properties, baking quality, nutritional quality and sensory quality. 


\section{Materials and Methods}

Wheat flour (Teer brand) and Maize flour were collected from local market. Other bread ingredients such as low-fat milk powder, shortening, sugar, dry yeast powder and salt were also procured from local market.

\section{Composite wheat flour and maize flour bread preparation}

Yeast-leavened composite bread was developed from the commercial formulation, adjusted to $180 \mathrm{gm}$ dough. The ingredients required are given in Table 1.

Table 1. Ingredients used for preparing bread

\begin{tabular}{|l|c|}
\hline \multicolumn{1}{|c|}{ Ingredients } & Amount (gm) \\
\hline Total flour & 100.00 \\
\hline Water & 64.00 \\
\hline Active dry yeast powder & 2.00 \\
\hline whole milk powder & 2.00 \\
\hline Shortening & 4.00 \\
\hline Sugar & 6.00 \\
\hline Salt & 1.50 \\
\hline
\end{tabular}

In the production of composite breads, the amount of maize flour levels included were $10,20,25,30$ and $40 \%$ of total flour. A part of sugar was dissolved in a portion of warm water. Dry yeast was added to that water to activate them. The remaining dry ingredients were transferred into a 5 liters capacity dough mixer. The flour plus the other ingredients were mixed with the water for first 2 minutes at speed 1 (lowest speed) and next 10 min at speed 2 (medium speed) in the dough mixer. The resulting dough was relaxed for 1 hours and 20 minutes in the processing unit at $28^{\circ} \mathrm{C}$. The relaxed dough was then removed from the cabinet and divided into desired dough size. Next, the divided dough was manually rounded up and first proofed for 15 minutes. Finally, the dough was manually molded and placed in the baking pan. The panned dough was next proofed at $28^{\circ} \mathrm{C}$ for $30 \mathrm{~min}$. the leavened dough was baked in the ready heated oven for $25-35 \mathrm{~min}$ at $200^{\circ} \mathrm{C}$. This modified method was used by Begum et al. (2011). Bread was also prepared by using $100 \%$ wheat flour as control. Five minutes after removal from the oven, the loaf was removed from the pan and allowed to cool to room temperature for 1 hour and then packed in the moisture and vapor proof polyethylene bag. The packed loaf was kept in the room temperature overnight for use in physical and sensory evaluations.

\section{Physico-chemical analysis}

Chemical composition, moisture content, fat content, protein content and ash content of the bread samples were determined by methods described by AOAC (1984). Crude fiber was estimated as per method of Ranggana (1991) and gluten of wheat flour and maize flour was measured according to Mis (2000). Carbohydrate content of bread samples were calculated by difference from 100, and energy was calculated using Atwater conversion factors. Bread volume, bread specific volume and the dough expansion were measured by the method described by Begum et al. (2011).

\section{Sensory evaluation}

Sensory evaluation of the composite bread samples were carried out by 10 panelists on a 9 point hedonic scale for different parameters such as color, aroma, taste, texture and overall acceptability as described by Ihekoronye and Ngoddy (1985). The 10 untrained panelists were teachers and students of Food Technology and Nutritional Science Department of Mawlana Bhashani Science and Technology University, Santosh, Tangail-1902, Bangladesh. Just before sensory test, loaves were cut into $2 \mathrm{~cm}$ thick slices. The end slices were discarded. $2 \times 2 \mathrm{~cm}$ squared pieces were prepared from each slice and placed in plates. Each plate was given six digit code numbers before testing. Hardness of bread was observed by the panelist using the scale of 1-5. 1-most soft bread texture and 5-most hard bread texture. Springiness of bread was observed by the panelist using the scale of 1-5 while 1=low elastic and $5=$ high elastic. Prepared breads were stored for three days in polyethylene sealed pack to observe staling in 
terms of the changes of hardness and springiness by the panelist. Staling is a term applied to a variety of chemical deteriorative changes, staling is usually manifested as adverse alterations of taste, odor, and texture in prepared foods which are not promptly eaten. The changes may lead to rejection of stale food but it may not be altered nutritionally.

\section{Data analysis}

Data found from the experiment were statistically analyzed using one way and two ways Analysis of Variance (ANOVA) at a 0.05 significance level. Duncan's Multiple Range Test (DMRT) was used to compare treatment means, if a significance difference was detected at a 0.05 level of significance.

\section{Result and Discussion}

\section{Chemical composition of wheat and maize flour}

Chemical composition of wheat and maize flour is given in Table 2. Maize flour has higher content of fat, crude fiber and ash, and lower content of protein than that of wheat flour compare to others.

Table 2. Chemical composition of wheat and maize flour

\begin{tabular}{|l|c|c|c|c|c|c|}
\hline Sample & Moisture (\%) & Protein (\%) & Fat (\%) & Ash (\%) & Fiber (\%) & Gluten (\%)DB \\
\hline Wheat & $13.09 \pm 0.14$ & $12.56 \pm 0.22$ & $0.85 \pm 0.04$ & $0.62 \pm 0.2$ & $0.68 \pm 0.17$ & 12.11 \\
\hline Maize & $12.15 \pm 0.21$ & $9.08 \pm 0.19$ & $1.15 \pm 0.10$ & $1.60 \pm 0.25$ & $1.25 \pm 0.13$ & 0 \\
\hline
\end{tabular}

Average of three replications

\section{Composite bread evaluation}

Composite wheat and maize flour bread were evaluated in terms of baking properties, dough expansion and sensory evaluation in order to ascertain the possibility of reducing wheat content in bread and replace them with locally available maize flour.

\section{Effect on baking properties of composite breads}

The results showed that substitution of wheat flour with maize flour reduced the baking potential in terms of volume and specific volume of loaf. Loaf volume and specific volume of $25 \%$ to $40 \%$ maize flour substitution were significantly different from $100 \%$ wheat flour bread. It was clearly observed that increase of percent substitution of wheat flour caused the decrease of loaf volume and specific volume of composite bread as shown in Fig. 1 and Fig. 2.

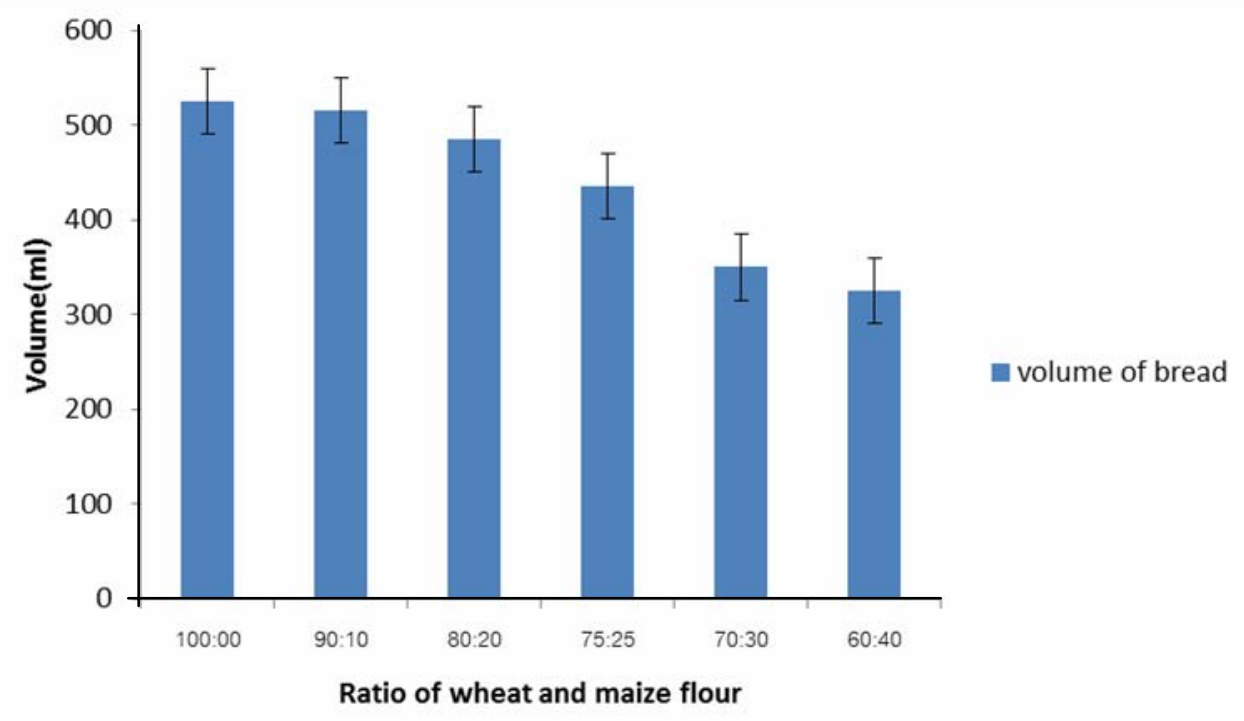

Fig. 1. Volume of composite flour bread containing wheat and maize flour 


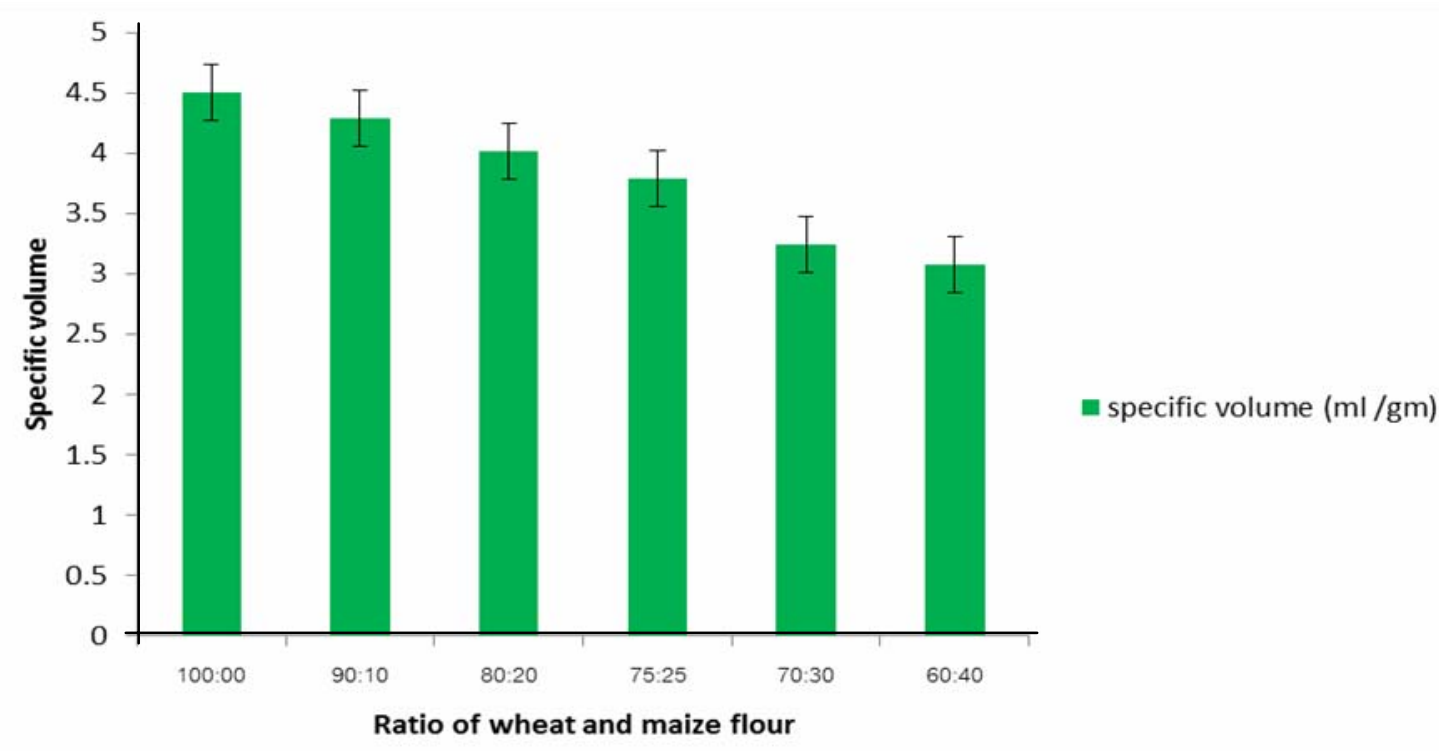

Fig. 2. Specific volume of composite flour bread containing wheat and maize flour

\section{Effect on dough properties of composite bread}

Dough properties of composite bread were examined in terms of dough expansion. During proofing time, dough could expand due to gas production and gas retention. Dough expansion was measured in terms of dough volume increase at every 10 minutes interval illustrated in Fig. 3. It was observed that wheat flour dough expanded much faster than any other combination. Rate of expansion of dough was decreased with the increase of maize flour addition. In composite bread dough wheat gluten was diluted by maize flour which cannot retain gas. The decrease of dough expansion using $10 \%$ maize flour substitution seems minimal as compared to higher substitution levels.

\section{Sensory evaluation of composite wheat and maize flour bread}

The acceptability of composite wheat and maize flour breads were determined in terms of sensory evaluation. Six parameters were considered under organoleptic tests including crumb colour, grain, aroma, taste, texture and overall acceptability (Table 3). It was observed that most of organoleptic characteristics also decreased with the increase of substitution level.

The panelists awarded higher scores for all of the sensory parameters of wheat bread than any combination of composite bread (Table 3). Table shows that maize flour substitution with wheat flour reduced the sensory quality of bread. The score for grain and aroma of $20 \%$ maize flour bread was not significantly different from wheat bread. Colour, taste and texture of $10 \%$ maize flour bread were not significantly different from wheat bread. Based on sensory data, the results indicated that the overall acceptability of composite bread was decreased with the increase of maize flour. Bread containing $10 \%$ maize flour was not significantly different from wheat bread. Bread produced from 30 to $40 \%$ maize flour showed lower scores and significantly different from wheat bread but not significantly different from each other. However, breads containing up to $10 \%$ maize flour were most acceptable in terms of sensory evaluation. The higher amount of maize flour was not accepted by the consumer in terms of overall internal and external appearances. Panelists commented that texture of bread of higher level of maize flour substitution was hard, dry and sandy. The results may be due to maize flour contain no gluten which is responsible for bread sensory and baking quality. 


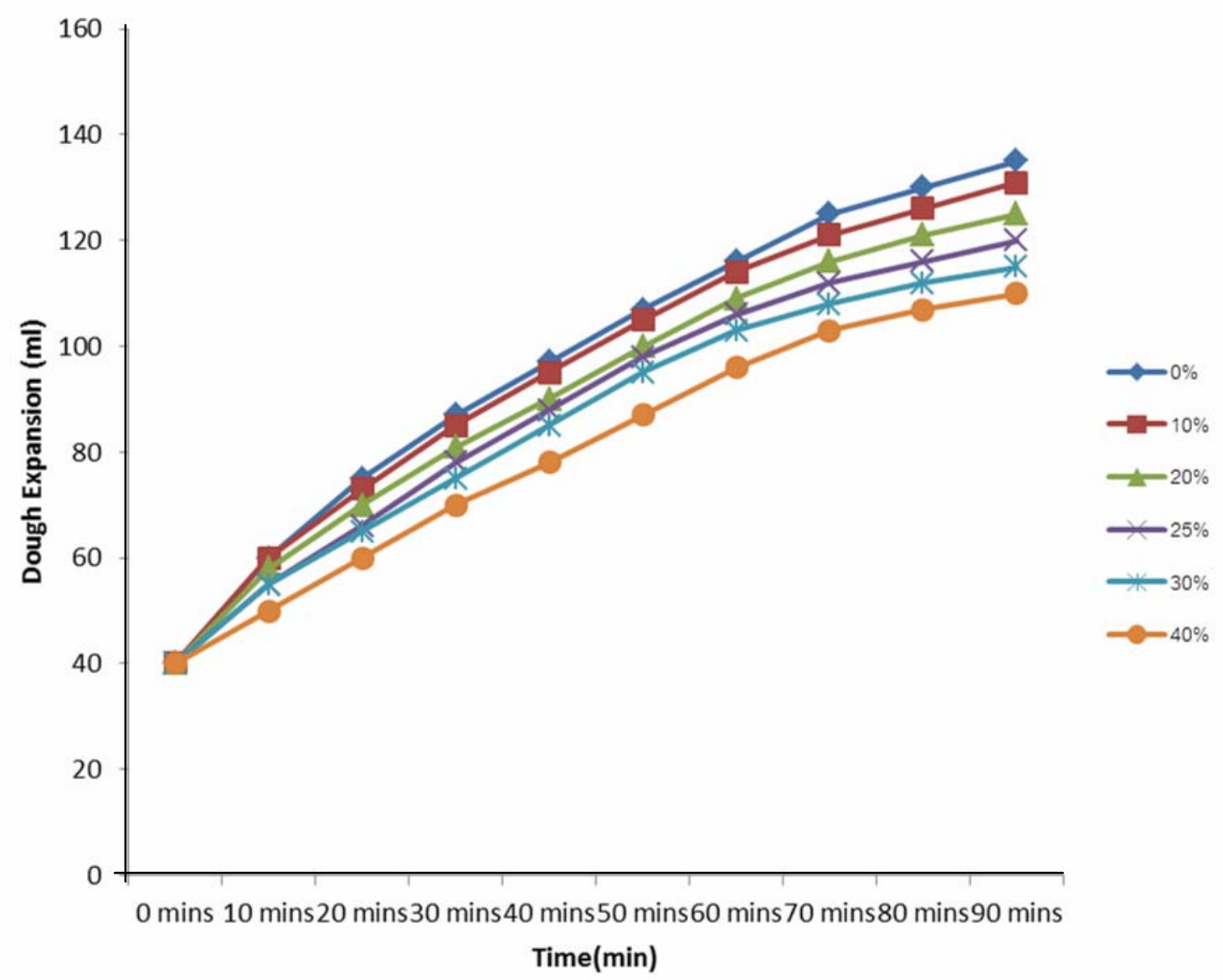

Fig. 3. Expansion of dough containing various levels of maize flour substitution in wheat flour

Table 3. Sensory evaluation of composite flour bread

\begin{tabular}{|l|c|c|c|c|c|c|}
\hline$\%$ Substitution & Grain & Crumb color & Aroma & Taste & Texture & Overall acceptance \\
\hline $\begin{array}{l}0 \%(100 \% \\
\text { wheat flour })\end{array}$ & $8^{\mathrm{a}}$ & $8.4^{\mathrm{a}}$ & $7.4^{\mathrm{a}}$ & $7.2^{\mathrm{a}}$ & $7.9^{\mathrm{a}}$ & $7.8^{\mathrm{a}}$ \\
\hline $10 \%$ & $7.1^{\mathrm{a}}$ & $7.3^{\mathrm{a}}$ & $6.7^{\mathrm{a}}$ & $6.6^{\mathrm{ab}}$ & $6.8^{\mathrm{a}}$ & $6.7^{\mathrm{b}}$ \\
\hline $20 \%$ & $6.9^{\mathrm{ab}}$ & $7.3^{\mathrm{a}}$ & $5.3^{\mathrm{b}}$ & $5.8^{\mathrm{b}}$ & $6.8^{\mathrm{a}}$ & $6.3^{\mathrm{b}}$ \\
\hline $25 \%$ & $5.9^{\mathrm{bc}}$ & $5.2^{\mathrm{b}}$ & $4.7^{\mathrm{b}}$ & $5.3^{\mathrm{b}}$ & $5.2^{\mathrm{b}}$ & $4.9^{\mathrm{c}}$ \\
\hline $30 \%$ & $5.2^{\mathrm{cd}}$ & $4.8^{\mathrm{b}}$ & $4^{\mathrm{b}}$ & $4^{\mathrm{c}}$ & $4.5^{\mathrm{b}}$ & $3.4^{\mathrm{d}}$ \\
\hline $40 \%$ & $4.7^{\mathrm{d}}$ & $5^{\mathrm{b}}$ & $4.1^{\mathrm{b}}$ & $3.5^{\mathrm{c}}$ & $4.9^{\mathrm{b}}$ & $2.6^{\mathrm{d}}$ \\
\hline
\end{tabular}

Mean of 10 scores for each sensory characteristics

Mean in column followed by the same letter are not significantly different at $95 \%$ confidence level.

The data for composite bread hardness are presented in Table 4. Results indicate that the hardness of composite bread was increased with the increase of substitution level of maize flour. There was no significant different in hardness of composite bread contain upto $20 \%$ maize flour. At $40 \%$ maize flour substitute level, the highest used in this study, bread gave highest hardness of composite bread. As maize flour cannot retain gas, it failed to give light textured spongy bread. Similar results were found by Khanitta (2000); Begum (2011) for rice flour and cassava flour based composite bread, respectively. 
Table 4. Effect of levels of maize flour on composite bread texture change during storage

\begin{tabular}{|l|c|c|c|c|c|c|}
\hline \multirow{2}{*}{$\%$ Substitution } & \multicolumn{3}{|c|}{ Firmness } & \multicolumn{3}{c|}{ Springiness (\%) } \\
\cline { 2 - 8 } & $1^{\text {st }}$ day & $2^{\text {nd }}$ day & $3^{\text {rd }}$ day & $1^{\text {st }}$ day & $2^{\text {rd }}$ day & $3^{\text {ay }}$ \\
\hline $0 \%$ (wheat bread) & $2^{\mathrm{a}}$ & $2.2^{\mathrm{a}}$ & $2.4^{\mathrm{a}}$ & $5.0^{\mathrm{a}}$ & $4.6^{\mathrm{a}}$ & $4.4^{\mathrm{a}}$ \\
\hline $10 \%$ & $2^{\mathrm{a}}$ & $2.5^{\mathrm{a}}$ & $3.0^{\mathrm{a}}$ & $4.8^{\mathrm{a}}$ & $4.4^{\mathrm{a}}$ & $4.1^{\mathrm{a}}$ \\
\hline $20 \%$ & $2^{\mathrm{a}}$ & $2.8^{\mathrm{a}}$ & $3.5^{\mathrm{b}}$ & $4.5^{\mathrm{a}}$ & $4.2^{\mathrm{a}}$ & $3.9^{\mathrm{a}}$ \\
\hline $25 \%$ & $3^{\mathrm{b}}$ & $3.2^{\mathrm{b}}$ & $3.3^{\mathrm{b}}$ & $4.1^{\mathrm{b}}$ & $3.8^{\mathrm{b}}$ & $3.5^{\mathrm{b}}$ \\
\hline $30 \%$ & $3^{\mathrm{b}}$ & $3.8^{\mathrm{c}}$ & $4.0^{\mathrm{c}}$ & $3.8^{\mathrm{b}}$ & $3.4^{\mathrm{c}}$ & $3.1^{\mathrm{c}}$ \\
\hline $40 \%$ & $3^{\mathrm{b}}$ & $3.5^{\mathrm{c}}$ & $4.5^{\mathrm{a}}$ & $3.5^{\mathrm{b}}$ & $3.1^{\mathrm{c}}$ & $2.8^{\mathrm{c}}$ \\
\hline
\end{tabular}

Average three replications

Mean in column followed by same letter are not significantly different at $95 \%$ confidence level.

Data for springiness of composite flour bread are presented in Table 4. Results showed that there was not significant different among the springiness of wheat bread at $10 \%$ and $20 \%$ maize bread. It was clearly observed that the springiness of composite bread contain maize decreased with the increase of substitution level.

\section{Effect on nutritional value of composite bread}

Wheat and maize flour composite bread were evaluated for nutritional value as shown in Table 5. Result showed that the proximate values for ash, fat, crude fiber and carbohydrate were lowest in whole wheat bread, which served as control and higher in maize substituted samples. The proximate values increased with increasing levels of maize substitutions.

Table 5. Nutritional values of composite wheat and maize flour breads

\begin{tabular}{|l|c|c|c|c|c|c|c|}
\hline$\%$ Substitution & $\begin{array}{c}\text { Moisture } \\
(\%)\end{array}$ & Protein (\%) & Fat (\%) & Ash (\%) & $\begin{array}{c}\text { Crude fiber } \\
(\%)\end{array}$ & $\begin{array}{c}\text { Carbohyd } \\
\text { rate (\%) }\end{array}$ & $\begin{array}{c}\text { Energy value } \\
(\text { Kcal/100gm) }\end{array}$ \\
\hline $\begin{array}{l}0 \%(w h e a t \\
\text { bread) }\end{array}$ & $37.39 \pm 0.05$ & $12.23 \pm 0.15$ & $4.04 \pm 0.12$ & $1.62 \pm 0.01$ & $2.48 \pm 0.02$ & 42.24 & 264.18 \\
\hline $10 \%$ & $35.63 \pm 0.06$ & $11.89 \pm 0.17$ & $4.11 \pm 0.04$ & $1.55 \pm 0.04$ & $2.58 \pm 0.03$ & 44.23 & 271.83 \\
\hline $20 \%$ & $35.55 \pm 0.06$ & $11.38 \pm 0.22$ & $4.13 \pm 0.07$ & $2.01 \pm 0.01$ & $2.64 \pm 0.02$ & 44.28 & 270.43 \\
\hline $25 \%$ & $35.31 \pm 0.04$ & $11.04 \pm 0.10$ & $4.12 \pm 0.10$ & $1.45 \pm 0.01$ & $2.74 \pm 0.02$ & 45.34 & 273.55 \\
\hline $30 \%$ & $35.37 \pm 0.06$ & $10.96 \pm 0.16$ & $4.15 \pm 0.13$ & $1.87 \pm 0.02$ & $2.86 \pm 0.01$ & 44.78 & 271.76 \\
\hline $40 \%$ & $35.71 \pm 0.05$ & $10.81 \pm 0.25$ & $4.16 \pm 0.09$ & $1.69 \pm 0.05$ & $2.95 \pm 0.02$ & 44.68 & 271.19 \\
\hline
\end{tabular}

Average of three replications

The carbohydrate content and energy values were highest in $25 \%$ maize flour bread, $(45.34 \%$ and 273.55 $\mathrm{Kcal})$ and lowest in wheat flour bread $(42.24 \%$ and $264.18 \mathrm{Kcal} / 100 \mathrm{gm})$, respectively. The composite breads contained energy values in the range of 270.43 to $273.55 \mathrm{Kcal} / 100 \mathrm{gm}$, and hence conformed to the $(\mathrm{FAO} / \mathrm{WHO}, 1994)$ recommended minimum energy content of $1674 \mathrm{~kJ} / 100 \mathrm{gm}$. The moisture contents of the composite breads decreased with maize flour substitution by a range of 37.39 to $35.31 \%$. There was also a decrease in the protein content $(12.23 \%$ to $10.81 \%)$ and fat content increased (4.04 to $4.16 \%)$ in composite breads produced from maize flour substitution. The crude fibre content of the composite bread showed a percentage increase in the range of 2.48 to $2.95 \%$ as the whole-wheat flour was substituted with maize flour. The crude fibre most likely represents variable fraction of dietary fibre and includes mostly the lignin, cellulose and hemicelluloses components (Mannay and Shadaksharaswany, 2005; Islam et al, 2007).

\section{Effect of composite flour on bread stalling}

Data for hardness and springiness of stored composite bread are presented in (Table 4). Formulated samples were stored for three days and observed the changes of hardness and springiness of bread by panelists. Results showed that hardness of composite bread was increased and springiness of composite bread decreased gradually with storage time and substitution level. 


\section{Conclusion}

This study has demonstrated that quality of composite bread has been adversely affected with the different substitution level of maize flour. Low cost and nutritionally rich, except protein content, maize flour may be used in composite flour bread preparation at the level of $10 \%$ with acceptable physical and sensory attributes.

\section{References}

AOAC. 1984. Official Methods of Analysis. $13^{\text {th }}$ ed., Association of Official Analytical Chemistry, Washington, D. C. 1018 p.

Begum, R., Rakshit, S.K. and Mahfuzur Rahman, S.M. 2011. Protein Fortification and Use of Cassava Flour for Bread Formulation. International Journal of Food Properties., 14:185-198.

Berghofer, E. 2000. Brot als "funktionales Lebensmittel". Getreide Mehl Brot., 54 (3):175-179.

Dewettinck, K., Van, Bockstaele, F., Kuhne, B., Van de Walle, Courtens, T., Gellynck, X. 2008. Nutritional value of bread: Influence of processing, food interaction and consumer perception. Rev. J. Cereal Sci., 48:243-257.

FAOWHONNU Expert Consultation. 1994. Food Nutrients Requirements, Report of a Joint FAOWHONNU Expert Consultation. World Health Organization Technical Report Series 724. Geneva: WHO.

Giami, G. Y., Amasisi, T., Ekiyor, G. 2004. Comparison of bread making properties of composite flour from kernels of roasted and boiled African bread fruit (Treculia africana) seed. J. Mat. Res., 1(1):16-25.

Ihekoronye, A. I., Ngoddy, P.O. 1985. Integrated Food Science and Technology for the Tropics. 2nd ed. Macmillan Publishers Ltd. London.

Islam, T., Chowdhury, A., Islam, M., Islam, S. 2007. Standardization of Bread Preparation from Soy Flour. Int. J. Sustain. Crop Prod., 2(6):15-20

Khanitta, M. 2000. Effect of emulsifiers on composite wheat, rice and brown rice flour bread characteristics. AIT thesis no. PH-0015. Pathumthani, Thailand.

Mannay, S., Shadaksharaswany, C.M. 2005. Foods: Facts and Principles. (2nd ed.). New Age International Ltd. Publishers. New Delhi, India.

Mejía, Danilo. 2003. MAIZE: Post-Harvest Operation, Food and Agriculture Organization of the United Nations (FAO).

Mis, A. 2000. Some methodological aspects of determining wet gluten quality by the Glutomatic Method (a laboratory note), International Agrophysics, 14, 263-267.

Ranganna, S. 1991. Manual of analysis of fruits and vegetable products. Tata McGraw Hill publishing Company Ltd. New Delhi. p. 9, 25-26.

Mejía, Danilo. 2003. MAIZE: Post-Harvest Operation, Food and Agriculture Organization of the United Nations (FAO), pp. 30. 